\title{
Hydrogeological Study In And Around Birendranagar Municipal- ity, Surkhet Valley, Mid-Western Nepal
}

\author{
Roshani B. C. ${ }^{1}$, Dinesh Pathak ${ }^{1 *}$ and Ramesh Gautam ${ }^{2}$ \\ 1 Central Department of Geology, Tribhuvan University, Kathmandu, Nepal \\ 2 Former Superintendent Hydrogeologist, Ministry of Irrigation, Government of Nepal
}

\begin{abstract}
This study is carried out in parts of Surkhet valley, which is one of the Dun valleys (Inner Terai) in Nepal. Tubewell data was collected, dug well inventory with water table measurement was carried out followed by the data analysis leading to the groundwater resource assessment of the study area. The subsurface sediment distribution in the study area consist clay, sand and gravel giving rise to multiple aquifer horizons. Groundwater potential map has been prepared for parts of Surkhet valley and groundwater resource assessment has been carried out for the entire valley. Groundwater potential map was prepared using various thematic layers. Weights and rank were assigned, respectively to each thematic layer and its classes based on their significance for the groundwater occurrence. Most of the study area has medium groundwater potential with low potential at north east and high potential at southeast of the study area. The groundwater resource assessment for the valley, carried out by water balance method and aquifer analysis reveals that there is good groundwater reserve in the valley that can significantly fulfill the water demand in the area if properly exploited with required management of land and water resources in the area.
\end{abstract}

Keywords: Groundwater resources, aquifers, groundwater potential, groundwater reserve

Accepted: 28 October 2020

\section{INTRODUCTION}

Groundwater is an important natural resource that fulfills huge irrigation water demand in India, China, Pakistan, Bangladesh and Nepal (Villholth and Sharma 2006). This natural resources plays a vital role in meeting various demands of human beings, however, it is heavily stressed due to overexploitation required to meet the increasing demand of the growing population (Pathak 2018). In order to use the groundwater for irrigation and drinking water purpose, it is necessary to properly explore the resource in view of the fact that the groundwater resources in Nepal have not been fully assessed (FAO 2011). The role of groundwater in providing water for agriculture, domestic, and industrial uses is emphasized from the fact that nearly half of all drinking water in the world and around 43 percent of all water effectively consumed in irrigation accounts the groundwater (WWAP 2009; Siebert et al. 2010). Groundwater is also considered as an important component required for sustaining of the streams, lakes, wetlands, and ecosystems. Because of the complexity and rapidly changing situation of water supply and use, it is very difficult to assess the adequacy of freshwater resources in future (Vörösmarty et al. 2000). In any situation, the availability of groundwater will be of prime importance to address the water shortage issues.

Groundwater that exists in the primary and secondary pore spaces in the soil, sediments and rock below the ground

${ }^{\star}$ Corresponding author

Email Address: dpathaktu@gmail.com surface. The primary input to the system is from rainwater while at the higher altitude area in the Himalaya, snowmelts significantly contribute water to the groundwater system. The petrological composition of the rocks greatly influences the hydro-chemistry of the groundwater (Mook et.al. 2001). Groundwater flows through the pore spaces from higher elevation to lower elevation and the water received from precipitation is added to the groundwater system, which then leaves the system either through nearby streams and river or through evapotranspiration (Pinder and Celia 2006; USGS 2018). The importance of groundwater in the study area is evidenced by the fact that many settlements in the Surkhet districts are having water crisis, especially for drinking, since long time (Gurung et al. 2019). Birendranagar municipality itself is hard hit by water shortage during the pre-monsoon season. Groundwater availability in the valley has been earlier assessed to some extent and the finer nature of the valley fill sediments is attributed for less availability of groundwater (Villholth and Sharma 2006). However, detailed analysis of the subsurface lithology from the water well drilling data has not been carried out.

This paper describes the hydrogeological condition in and around the Birendranagar Municipality, Surkhet District. The area belongs to the Doon valley within the Siwalik region. The purpose of the study is to assess present groundwater resources and assess the annual dynamic groundwater reserve in the valley. The necessity of this study is felt from the fact that the detailed study in the assessment of groundwater resources of the valley has not be previously carried out. The data analysis 
has been carried out in geographic information system (GIS) leading towards the preparation of groundwater potential map of the study area. GIS has been widely used in the preparation of related database, analysis and groundwater potential map preparation in different regions of Nepal Himalaya (Pathak 2017; Pathak 2016; Pathak and Shrestha 2016). The study is of prime importance from the fact that the global water supply is potentially important in view of global climate change (Vörösmarty et al. 2000; Kumar 2012; Smerdon 2017; Beniston and Stoffel 2014). In addition, water availability in the Surkhet valley is limited as it has isolated groundwater basins in contrast to the Terai Plain in which the groundwater belongs to that of a larger system of Indo-Gangetic basin (Kansakar 2005).

\section{The Study Area}

The study area, Birendranagar municipality lies in the Surkhet District and is the capital city of Karnali Province, with an average elevation of $700 \mathrm{~m}$ above sea level (Fig. 1). The district area is $2451 \mathrm{~km}^{2}$ out of which Birendranagar occupies an area of $54 \mathrm{~km}^{2}$. Surkhet valley has sub-tropical climate and receives intense monsoon rain (about 83\%) between June and September and the average annual rainfall in the valley is 1453 $\mathrm{mm}$ (DHM 2016). The maximum and minimum temperatures ever recorded in Birendranagar were $41.8^{\circ} \mathrm{C}$ and $-0.7^{\circ} \mathrm{C}$. It is drained by several north-south flowing rivers, namely Bhureli Khola, Karke Khola, Itram Khola and Geru Nadi. These perennial rivers join each other to form Nikash Khola, which is the tributary of Bheri River.

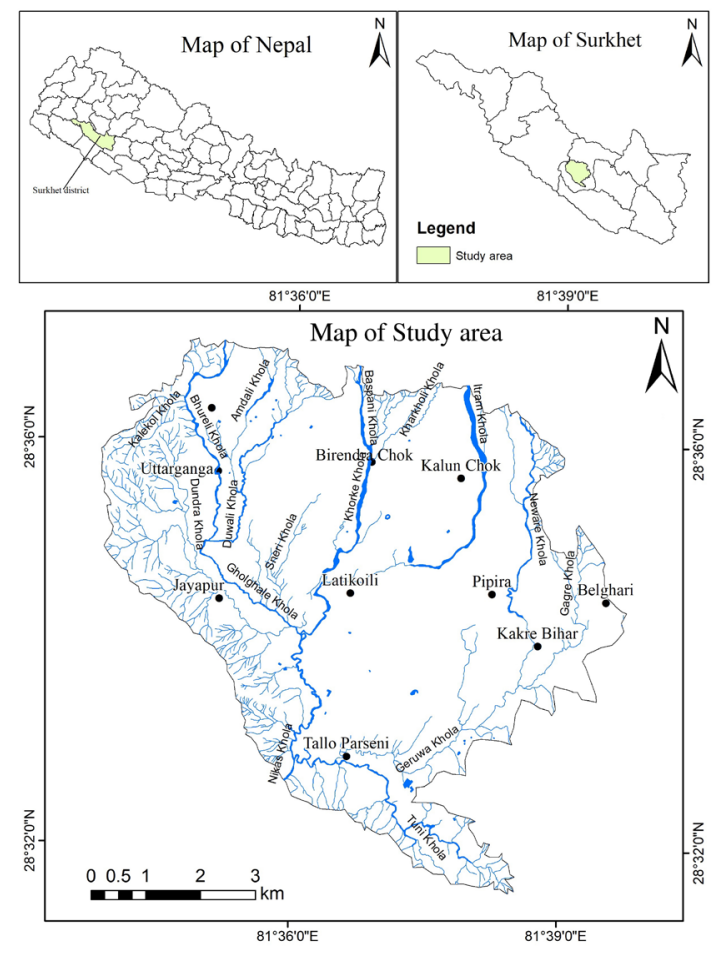

Fig. 1: Location map of the study area

\section{Geology of the Study Area}

The study area lies in the Surkhet dun valley. Dun valley is the wide-opened basins in the Siwaliks (Kimura 1994). Dun valleys are the tectonic valley situated in the Siwalik that has neotectonic significance. Further, the valley has distinct hydrogeologic setup as it is represented by thick pile of sediments with varying thickness of aquifer materials at different depths. The bedrock in the study area comprises of Middle Siwalik rocks consisting of thick bedded sandstone and mudstone overlain by coarse to fine alluvial sediments of Quaternary age (Dhital 2015; Shrestha et al. 1987). The rock formation exposed in the southern part of the Birendranagar is of Siwalik Group, which is marginally exposed in the north of the valley and end up at the main Boundary Thrust (MBT) that separates the Siwalik rock sequence in the south from the Lesser Himalayan rock sequence comprising of sedimentary and meta-sedimentary rocks in the north (Shrestha et al. 1987). The core area of the Surkhet valley is filled with younger, unconsolidated and loose sediments of Quaternary age that contain groundwater reserve. Dun valley can be considered as isolated groundwater basins and the hydrogeology of Surkhet dun valley is least studied.

\section{MATERIAL AND METHODS}

This study comprises of primary and secondary data. The primary data was collected from field survey while the source of secondary data was mainly available reports and maps. Field investigation was carried out using a systematic field data sheet in order to collect the detailed information required to assess the hydrogeological condition of the area. Observations were made at different locations measuring the water table, well depth and water level fluctuation. Global Positioning System (GPS) was used to obtain the coordinates of the observation point and the topographical map $(1: 25,000)$ was used as base map in the field. The litho-logs as well as aquifer parameters of the water wells were collected from the concerned government office. All together lithologs of 19 deep tube wells were used in the study (Table 1).

Table 1: List of deep tube wells used in the study

\begin{tabular}{|c|l|c|c|c|c|}
\hline \multirow{2}{*}{ S.N. } & \multicolumn{1}{|c|}{ Location } & \multicolumn{2}{|c|}{ Coordinate } & Elevation (m) & Depth of well (m) \\
\cline { 3 - 4 } & & Longitude & Latitude & & \\
\hline 1 & Dhulabit, Surkhet & 81.649975 & 28.5698527 & 650 & 40 \\
\hline 2 & Pipira, Surkhet & 81.6403722 & 28.5680222 & 649 & 50 \\
\hline 3 & Chaukedhunga, Surkhet & 81.6383611 & 28.5573694 & 635 & 45 \\
\hline 4 & Charkune, Surkhet & 81.6378277 & 28.5510500 & 637 & 70 \\
\hline 5 & Bangesimal, Surkhet & 81.5761666 & 28.6087611 & 679 & 70 \\
\hline 6 & Koldada, Surkhet & 81.5791916 & 28.5971194 & 673 & 60 \\
\hline 7 & Bhureli, Surkhet & 81.5848194 & 28.5932416 & 654 & 50 \\
\hline 8 & Kalagau, Surkhet & 81.5997833 & 28.6058305 & 691 & 60 \\
\hline 9 & Mulpani, Surkhet & 81.5994666 & 28.5990277 & 683 & 48 \\
\hline 10 & Pateni, Surkhet & 81.6048416 & 28.5852333 & 659 & 60 \\
\hline 11 & Mulpani, Surkhet & 81.5979138 & 28.5981666 & 669 & 48 \\
\hline 12 & Naulapur, Surkhet & 81.6181138 & 28.5887777 & 661 & 58 \\
\hline 13 & Bureli, Surkhet & 81.6330888 & 28.5908777 & 650 & 48 \\
\hline 14 & Pipira, Surkhet & 81.6407416 & 28.5791111 & 664 & 35 \\
\hline 15 & Dhodekhali, Surkhet & 81.5861666 & 28.6079000 & 693 & 57 \\
\hline 16 & Pateni, Surkhet & 81.6048416 & 28.5852333 & 659 & 80 \\
\hline 17 & Bangesimal, Surkhet & 81.5761666 & 28.6087611 & 679 & 75 \\
\hline 18 & Bureli, Surkhet & 81.5848194 & 28.5932416 & 654 & 30 \\
\hline 19 & Kalagau, Surkhet & 81.5997833 & 28.6058305 & 691 & 60 \\
\hline
\end{tabular}


Hydrogeological database of the study area was prepared in GIS and different thematic maps were prepared. The hydrostratigraphic units were demarcated from the several lithological cross-sections in the area leading to the preparation of fence diagram showing distribution of different aquifer horizons (unconfined and confined) within the study area in three dimensions. The shallow groundwater potential map of the study area was prepared through the analysis of different thematic layers, like aquifer thickness, water table, and drainage density. The hydrogeological parameters couldn't be considered due to lack of pumping test data.

\section{RESULTS AND DISCUSSION}

\section{Groundwater Exploitation}

The groundwater in the Indo-Gangetic Plain (Bhabar and Terai) is abundantly available and hence it is adequately exploited for drinking and irrigation as well as industrial purposes. Even in the Bhabar zone of the Indo-Gangetic Plain, the availability of water for drinking and irrigation purpose is always the matter of challenge. In contrast to the Indo-Gangetic Plain, the groundwater system in the dun valley (Inner Terai) is rather more complicated, especially in terms of recharge and discharge condition. Groundwater in the study area (Inner Terai or Dun valley) is mainly exploited through deep tube wells and dug wells. Groundwater exploration, especially for drinking and to some extent for irrigation purpose in the study area is at growing stage. However, the data on well particulars (lithologs, water table, pumping test data and hydrogeologic parameters) are not well maintained and not easily available. It is also evidenced from the fact that in spite of laborious search in government and private organizations, the litho-logs of only 19 deep tube wells could be collected and no other information could be obtained. The well depths range from 30 $\mathrm{m}$ to $80 \mathrm{~m}$ and gravel as well as sand layers comprises of good aquifer forming the groundwater reservoir in the valley. The dug wells are abundantly used for the irrigation and domestic purpose in the study area. As per the available data, it appears that only shallow (unconfined and shallow confined) aquifers are explored and exploited till data and the deep aquifer exploration is yet to be carried out.

\section{Drainage Density}

The drainage system in an area is the function of slope, fracture pattern, major lineaments, rock type, rainfall etc. Drainage is well visible on remote sensing imagery reflecting the varying lithology and structure of a given area that has significant connection with the groundwater recharge and hence with the availability of the resource (Pathak and Shrestha 2016). The drainage density map of the study area shows that most of the area is covered by moderate drainage density while the areas with high and low drainage density cover comparatively less area (Fig. 2). The high drainage density refers to the increased overland flow of water thereby reducing the subsurface percolation while the low drainage density provides better condition for improved infiltration resulting in better groundwater potential.

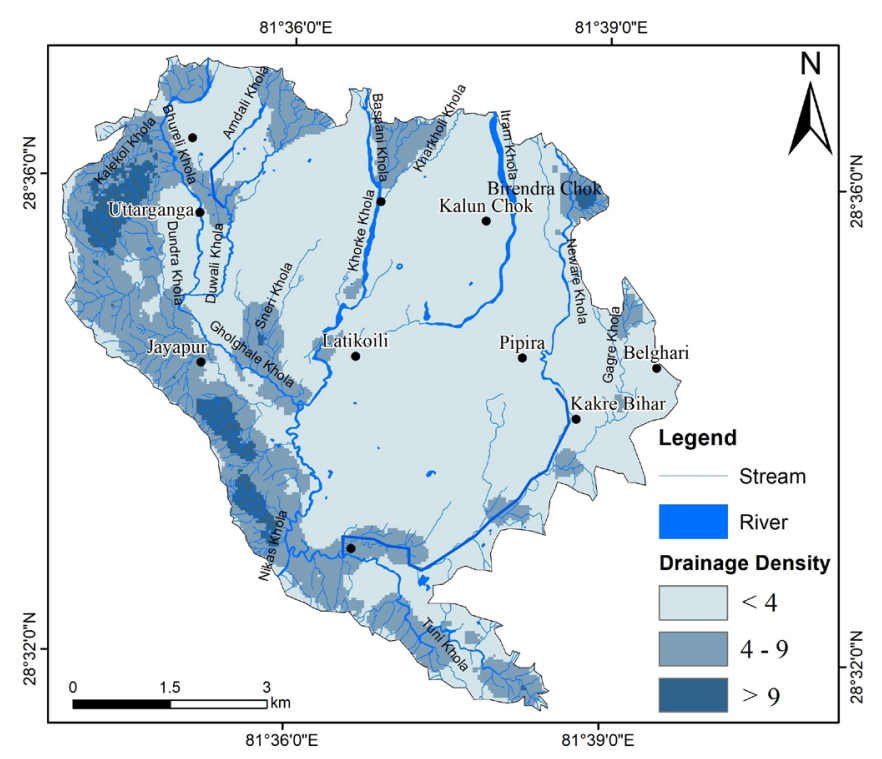

Fig. 2: Drainage density $(\mathrm{m} / \mathrm{km} 2)$ map of the study area

\section{Water table}

The water table depth was assessed at 19 observation points. The water table depth varies from 0.1 to $13.1 \mathrm{~m} \mathrm{bgl}$ (Fig. 3). The water table is deeper at the northern part while it is shallow at the southern part. The deeper water table in the northern and western part of the study area indicates the presence of thick sequence of coarser materials. This can be correlated to the recharge area (Bhabar zone) in Nepalese Terai (Pathak 2016; Rao and Pathak 1996, Rao et al. 1996). The southward fining nature of the sediments has resulted in the presence of shallow water table.

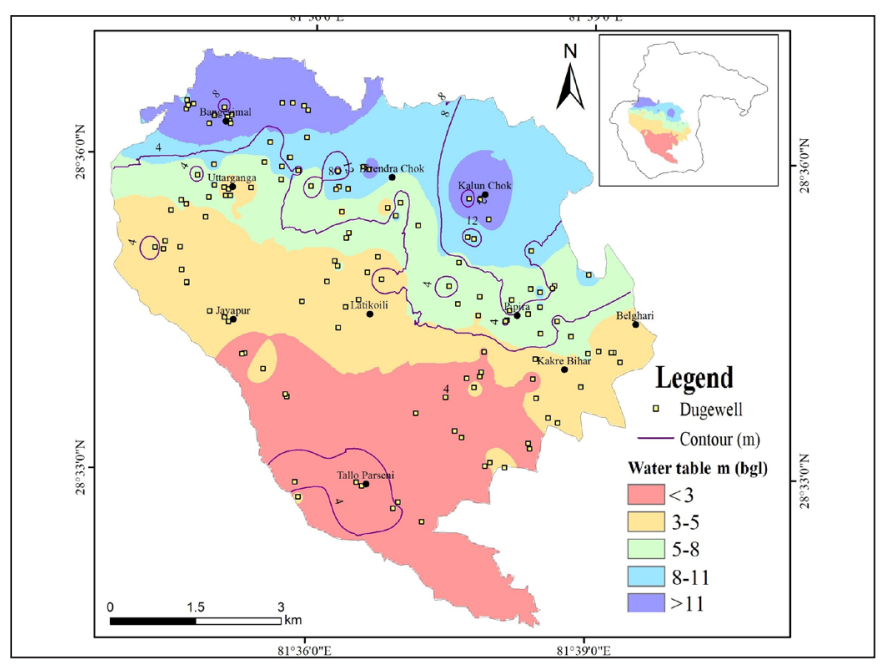

Fig. 3: Groundwater contour below ground level in the study area 


\section{Groundwater Flow}

Since the groundwater movement is slow through pore spaces or other openings in the rocks, the movement depends upon openings in rocks, porosity, permeability, specific yield and specific retention (Todd and Mays 2005). The groundwater table above mean sea level is calculated deducting the elevation of well location from the water table measured below ground level. This will facilitate to draw groundwater flow direction as the water flows from higher elevation to lower elevation. Groundwater in the study area flow towards the south and hence the water table is shallow at the southern part (Fig. 4).

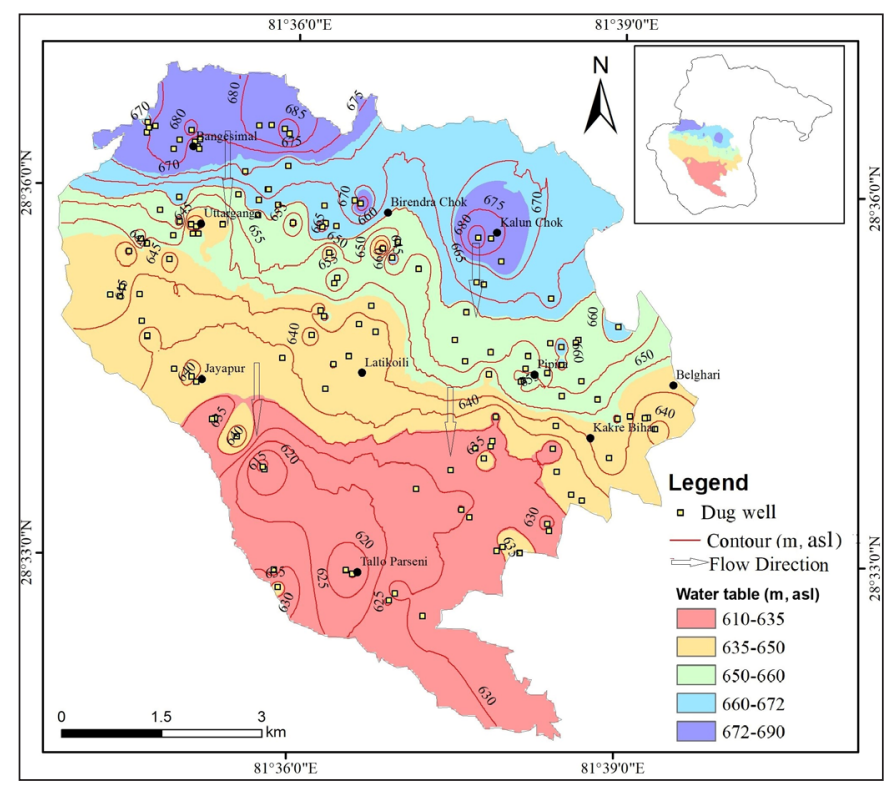

Fig. 4: Groundwater contour above sea level (asl) showing ground water flow direction

\section{Sub-surface geology and hydrostratigraphic units}

Among the 19 boreholes drilled in the valley, the maximum depth of bore hole lies at the central part of the valley is 80 $\mathrm{m}$. Sub-surface geology in the study area has been delineated based on the lithological data of the tube wells (Fig. 5). The valley is filled with the sediments transported from the surrounding hills, therefore, the valley part is hydrogeologically represented by multi-aquifer horizons. The lithologs were plotted along several cross sections and interpreted to establish the hydrostratigraphic units along the sections and a fence diagram has been prepared showing the aquifer layers in 3 dimensions.

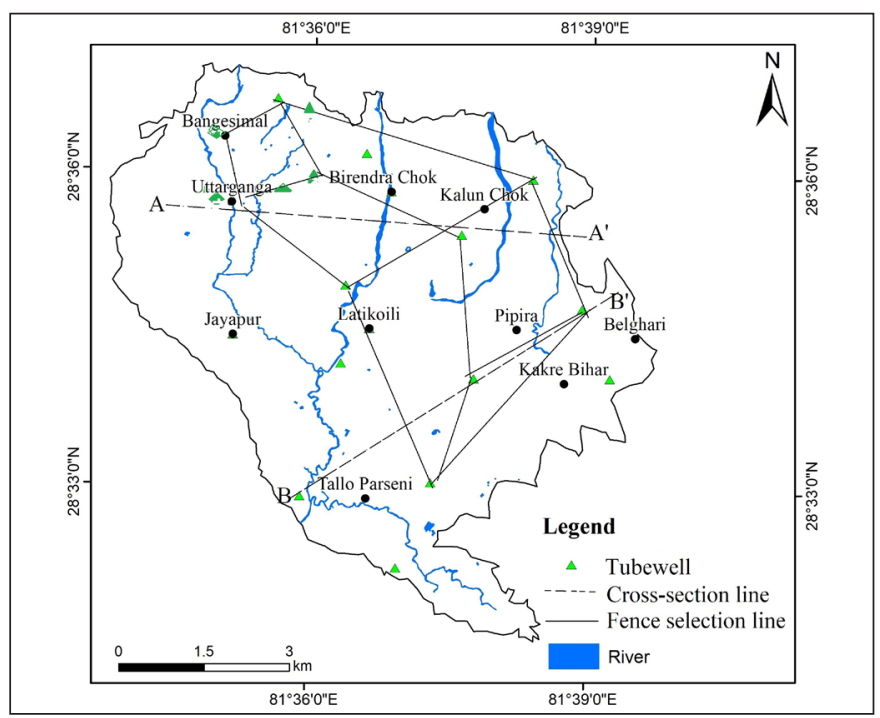

Fig. 5: Well location with the cross-section and fence lines

The valley fill sediments are thick in the southern part and thin in the northern part of the valley. The lithological data shows that finer sediments are dominantly present in the central part of the valley where as coarse granular sediments lie around the surrounding foot hills. The NE-SW section shows that the thickness of gravel and sand is more in the northern and southern part, while it is thinly distributed in the central part (Fig. 6a). The multilayer of gravels and sand give rise to the unconfined and confined aquifers. The depth of borehole is around $80 \mathrm{~m}$ in the south showing much thicker layers of permeable materials. The east-west section shows the dominance of fine-to-medium sized sediments, especially clay, sandy clay and gravel (Fig. $6 \mathrm{~b})$. The sediment distribution clearly shows that the sediment size and thickness of coarser material increases from north to south in the study area. The thickness of unconfined aquifer is more in the northern part of the study area, which is almost negligible at the central part as observed in the lithological sections interpreted to hydrostratigraphic units.

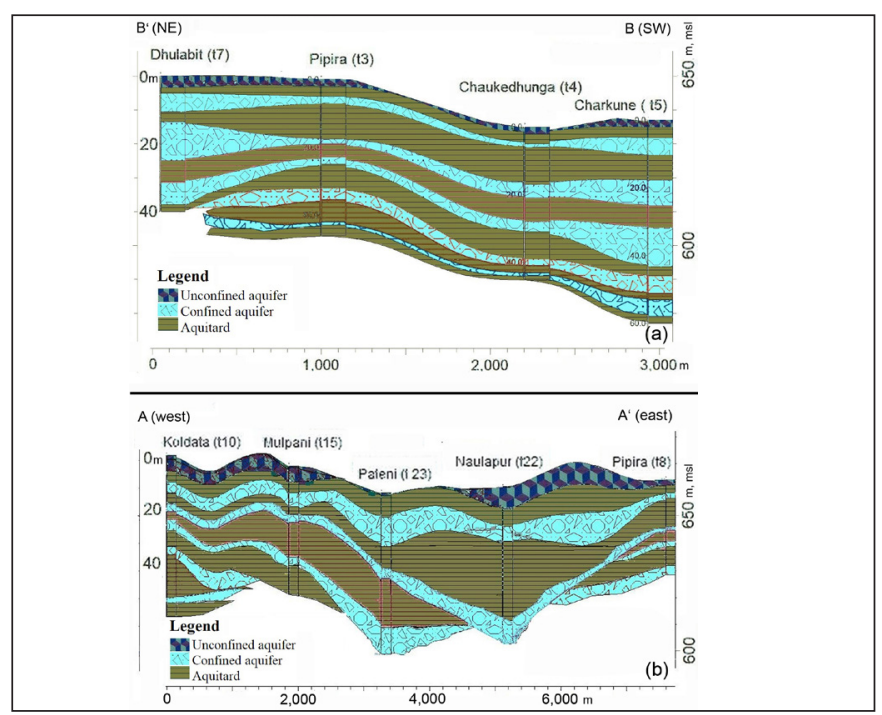

Fig. 6: Hydrostratigraphic units interpreted from lithological crosssection along (a) northeast-southwest, and (b) east-west direction. Cross section lines are shown on Fig. 5 
A fence diagram has been prepared showing the distribution of hydrostratigraphic units in the study area (Fig. 7). Confined aquifer consisting of coarser materials, are mostly distributed in south-eastern part of the study area. Thick aquitard layer consisting of finer materials (clay, silty clay etc.) are mostly distributed in north-western part.

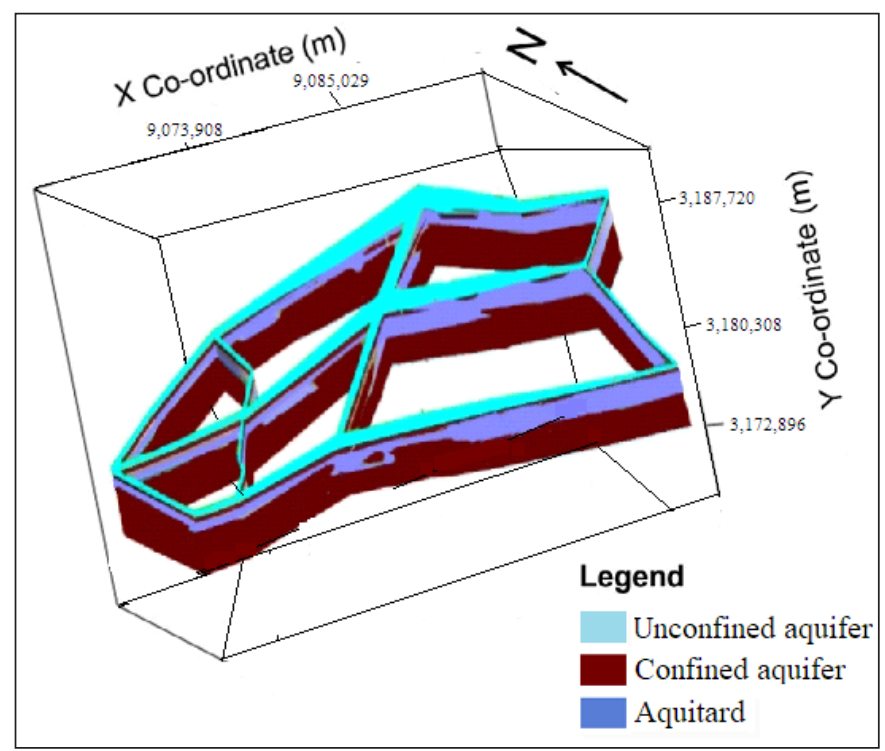

Fig. 7: Fence diagram showing the hydrostratigraphic units in the study area (fence lines are shown on Fig. 5)

\section{Aquifer thickness}

Todd (1980) defined an aquifer as "a geologic formation containing sufficient saturated permeable material to yield significant quantities of water to wells and springs". In order to properly understand the hydrogeological system, the aquifer parameters are to be well explored. Among the aquifer parameters, porosity is an important parameter that is related to the capacity of aquifer to release the water held in its pores and also its ability to transmit the flow (Subramanya 2013). On the basis of their occurrence, aquifers in the area have been classified as confined and unconfined aquifers. The spatial variation of the thickness of aquifers shows that the thickness of unconfined aquifer ranges from $10 \mathrm{~m}$ to 50 $\mathrm{m}$ and the northwestern part dominantly represents thin layer of unconfined aquifer (Fig. 8a). Likewise, the thickness of confined aquifer ranges from $9 \mathrm{~m}$ to $42 \mathrm{~m}$ and the south western part consists of thick aquifer layers (Fig. 8b).

The thickness of aquifer material within the drill depth of around $80 \mathrm{~m}$ has been calculated incorporating both the unconfined and confined aquifers (Fig. 9). The resulting map is used for the preparation of groundwater potential map of the area.

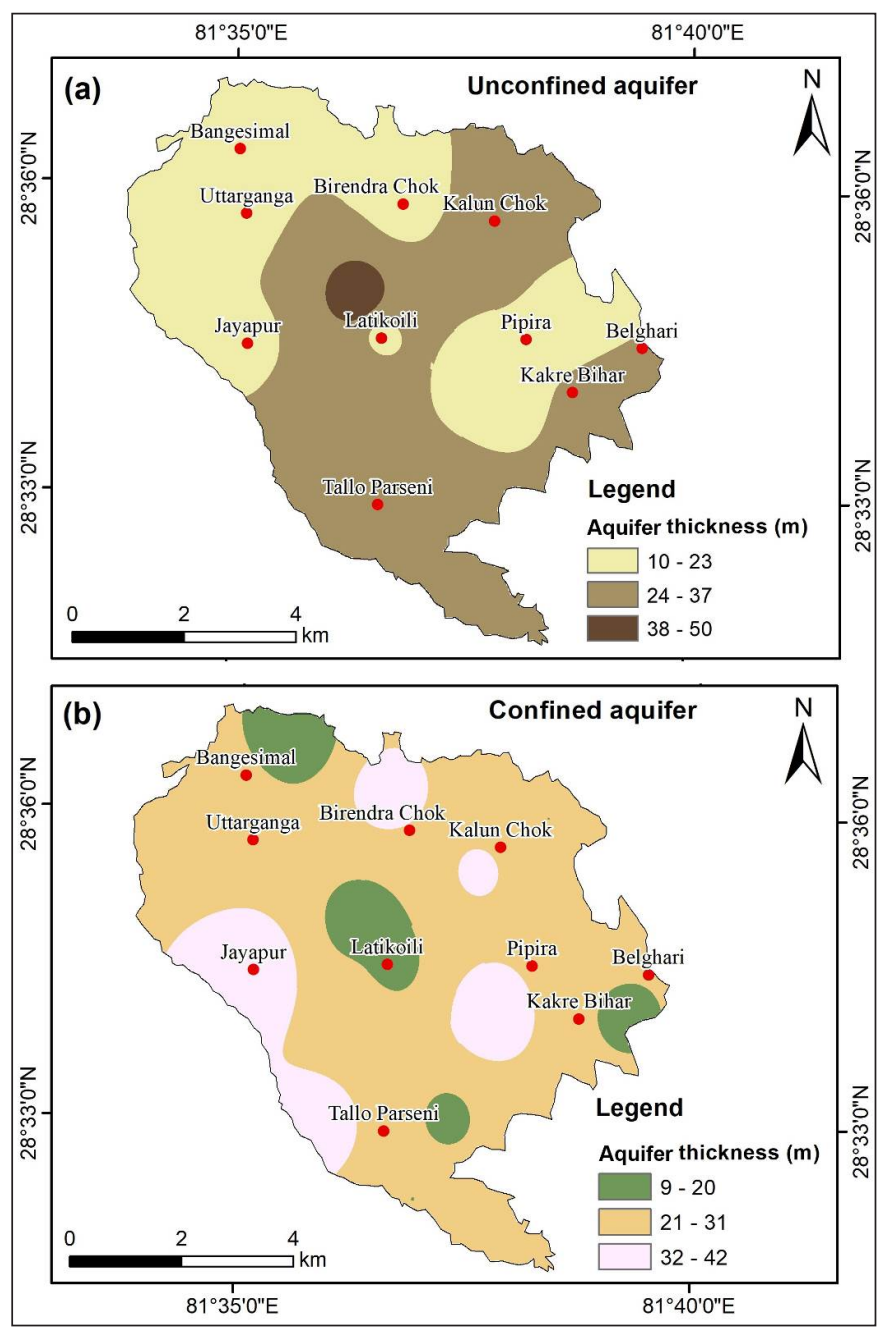

Fig. 8: Spatial variation of thickness of (a) confined aquifer, and (b) unconfined aquifer

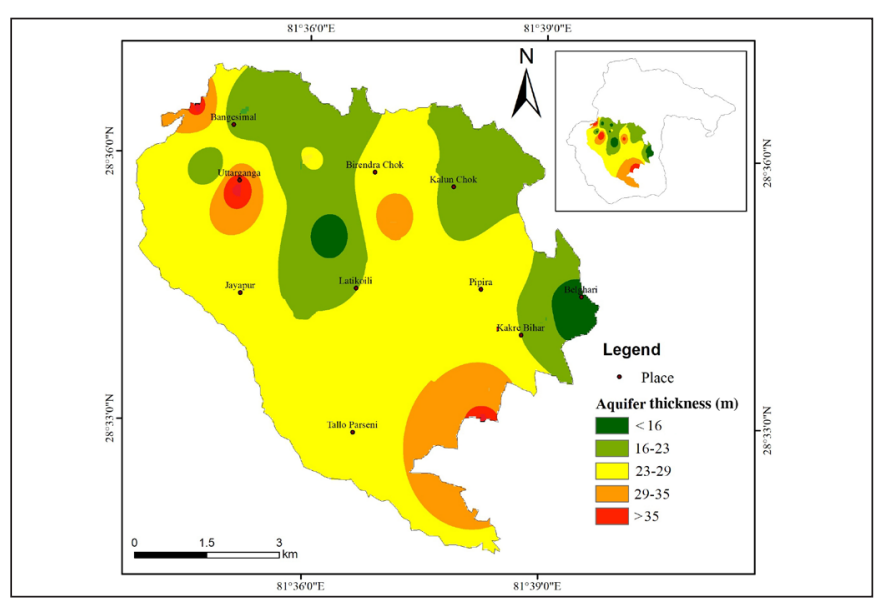

Fig. 9: Cumulative thickness of aquifer material (unconfined and confined aquifer) within the drill depth $80 \mathrm{~m}$ 


\section{Groundwater potential mapping}

For the groundwater potential mapping three different thematic layers (parameter maps), namely drainage density (Fig. 2), groundwater level m bgl (Fig. 3), and aquifer thickness within drill depth $80 \mathrm{~m}$ (Fig. 9) have been used. The weights and ranks were assigned, respectively to the thematic layer (parameter map) and its classes (Table 2). The minimum weight is given to the drainage density parameter map because the valley itself has a low drainage density, favoring for groundwater recharge. Likewise, equal weights have given to the thematic layer of groundwater level (below ground level) and aquifer thickness (cumulative of unconfined and confined aquifers). The shallow water table and thick aquifer layer is favorable for groundwater occurrence.

Table 2: Weight and rank assigned to different thematic layers (Parameter maps)

\begin{tabular}{|c|l|c|l|c|}
\hline S. N. & \multicolumn{1}{|c|}{ Parameters } & Weight & \multicolumn{1}{c|}{ Classes } & Rank \\
\hline 1 & Drainage Density $\left(\mathrm{m} / \mathrm{km}^{2}\right)$ & 30 & Low $(<4)$ & 3 \\
\cline { 4 - 5 } & & & Moderate $(4-9)$ & 2 \\
\cline { 4 - 5 } & & 35 & High $(>9)$ & 1 \\
\hline 2 & \multirow{2}{*}{ Aquifer thickness } & & Thin $(<23 \mathrm{~m})$ & 1 \\
\cline { 4 - 5 } & & & Moderate $(23 \mathrm{~m}-35 \mathrm{~m})$ & 2 \\
\cline { 4 - 5 } & & 35 & Shallow $(<3 \mathrm{~m}$ bgl $)$ & 3 \\
\hline & & Groundwater level $(\mathrm{m}$ bgl $)$ & Moderate $(3-8 \mathrm{~m}$ bgl $)$ & 2 \\
\hline & & & Deep $(>8 \mathrm{~m}$ bgl $)$ & 1 \\
\hline
\end{tabular}

The product of integration of the three parameter maps is the groundwater potential map (Fig. 10). The groundwater potential map shows that the north eastern part of the study area is represented by low potential while south eastern part is having high potential. Most of the study area is occupied by moderate groundwater potential.

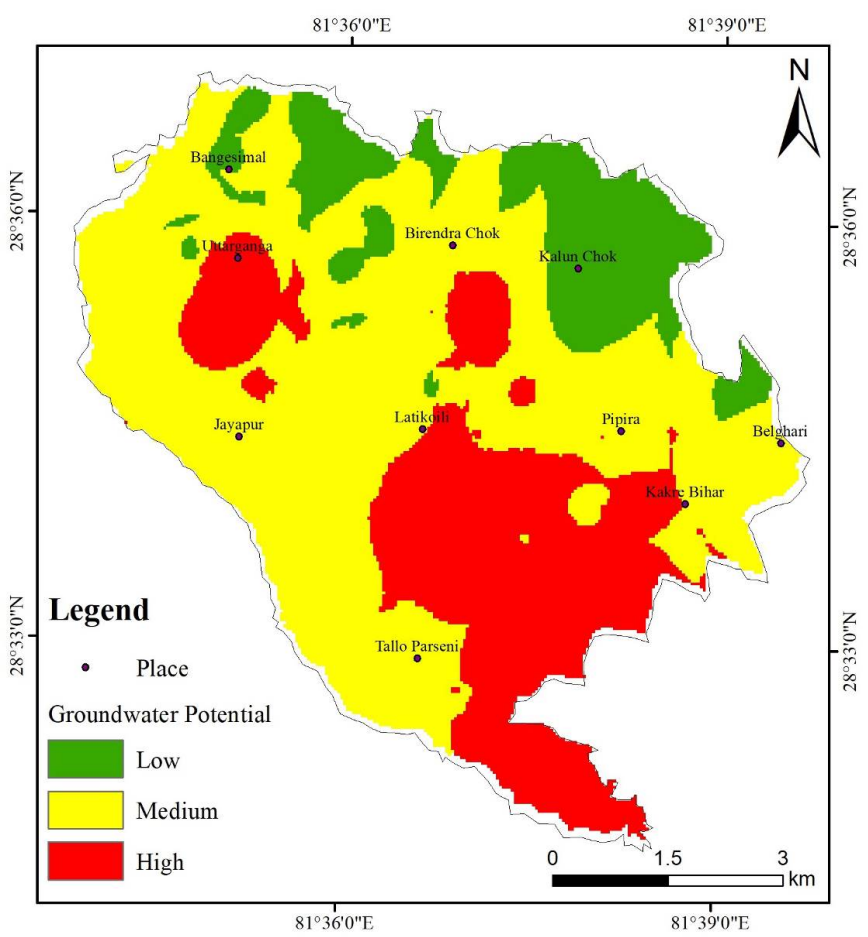

Fig. 10: Groundwater potential map of the study area

\section{Groundwater reserve estimation for the Surkhet valley}

Groundwater reserve estimation in the valley has been done through two different methods. The first method utilizes the water balance approach while the second method is based on the aquifer analysis.

\section{Water balance method}

Input in the system is the groundwater recharge for which rainfall is the main source of water. The groundwater recharge in the valley can be calculated using he drainage area and average annual rainfall. The drainage area is $111.59 \mathrm{~km}^{2}$ (i.e. $111590000 \mathrm{~m}^{2}$ ), while the average annual rainfall in the valley is $1453 \mathrm{~mm}$ (i.e. $1.453 \mathrm{~m}$ ). Total Annual water received by the valley is the product of drainage Area and average annual rainfall $\left(111590000 \mathrm{~m}^{2} * 1.453 \mathrm{~m}\right)$, which comes to be 162.14 $\mathrm{Mm} 3 /$ year.

The outputs from the system are through direct runoff from the Nikash Khola (the only outlet to discharge the surface water from the valley) and evapotranspiration. The average annual discharge from the Nikash Khola is 41,972,573 m3, which comes to be $41.97 \mathrm{Mm} 3 /$ year (DHM 2016). Since the evapotranspiration data for the Surkhet valley is not available, it is estimated with reference to that of the Chitwan valley as both the valleys are under similar geomorphic and geologic setup. Neupane and Shrestha (2009) calculated the evapotranspiration for Chitwan Valley which is $27.69 \%$ of the rainfall. Thus for the Surkhet valley, it can be assumed about $25 \%$ losses takes place due to evapotranspiration, which is $40.53 \mathrm{Mm}^{3} /$ year $(25 \%$ of 162.14$)$. Thus, the total annual water loss from the valley is $82.5 \mathrm{Mm}^{3} /$ year (total of discharge from surface water and loss from evapotranspiration).

The annual groundwater recharge or percolation within ground is calculated as $79.64 \mathrm{Mm} 3$ (Million meter cube). This value is obtained by subtracting the total annual water loss from the valley from the total annual input in the valley from rainfall (i.e. 162.14 Mm3 - 82.5 Mm3).

\section{Aquifer analysis method}

This is an alternative method to find out renewable groundwater resource. Theoretically, annual groundwater recharge in an area can be calculated very precisely from this method if the groundwater monitoring data is available. A rough estimation has been done for Surkhet valley as such data is not available. The Surkhet valley can be considered as having close groundwater system in which the inflow into the basin from other basins and outflow to other basins does not take place. Thus, the annual renewable ground reserve can be calculated by aquifer analysis considering the borehole lithologs interpreted to hydrostratigraphic units. 
The average aquifer thickness is obtained as $14.55 \mathrm{~m}$ and the areal extension of the aquifer is $47.83 \mathrm{~km}^{2}$ that gives the total volume of the aquifer as $695.93 \mathrm{Mm} 3$. The aquifer materials of study area are sand and gravels, for which the specific yield is $15 \%$. Thus, the annual renewable groundwater availability from the valley is $104.39 \mathrm{Mm} 3$, which is the product of total volume of the aquifer and specific yield $(695.93 \mathrm{Mm} 3 * 0.15)$.

Thus, the annual renewable groundwater reserve in the valley is calculated to be $79.64 \mathrm{Mm} 3$ and $104.39 \mathrm{Mm} 3$, respectively from the water balance method and aquifer analysis method. If we assume the renewable groundwater reserve per year as $104,388,975 \mathrm{~m}^{3}$, it can be exploited at the rate of 285,997 $\mathrm{m}^{3} /$ day through properly constructed tube wells. Thus, the groundwater reserve can sufficiently fulfill the required demand of about 50 thousand population of the Birendranagar municipality and is also available for adjacent areas. However, the groundwater recharge in the valley is expected to be affected from the change in land use condition in the area that has experienced remarkable changes in recent past. There is about $24 \%$ average annual growth rate of urban area at the expense of agriculture land and to some extent the forest area between 1989 and 2016 (Rijal et al. 2018). In this context, an approach for land and water management activities should be effectively carried out so as to ensure sustainable availability of groundwater for the people living in the area.

\section{CONCLUSIONS}

Surkhet valley is one of the intermontane tectonic basins, also called Dun valley, is surrounded by Siwalik hills and Birendranagar municipality occupies major part of the valley. The study shows the northeastern part of the study area is represented by low groundwater potential and southeastern part by high potential while most of the study area is represented by moderate groundwater potential. The main groundwater recharges sources in the study area are rainfall and surface water. The area is represented by multi-aquifer horizons with an unconfined aquifer and several confined aquifers. The water level in the study area varies from $0.113 \mathrm{~m}$ to $13.1 \mathrm{~m}$ below ground level and the groundwater generally flows from north towards south in the study area. The annual groundwater recharge in the Surkhet valley is calculated as $79.64 \mathrm{Mm} 3$ from the water balance method and $104 \mathrm{Mm}^{3}$ from aquifer analysis. The groundwater can be sufficiently exploited to meet the growing demand. The exploitation of deep aquifer may address the water scarcity issues in the valley. However, for the sustainable exploitation of the resources, proper land and water management activities in the valley should be practiced.

\section{REFERENCES}

Beniston, M. and Stoffel, M., 2014. Assessing the impacts of climatic change on mountain water resources. Science of the
Total Environment, v. 493, pp. 1129-1137. doi: 10.1016/j. scitotenv.2013.11.122

Dhital, M. R., 2015. Geology of the Nepal Himalaya - Regional Perspective of the Classic Collided Orogen. Springer Cham, $498 \mathrm{p}$

DHM, 2016. Meteorological data of Birendranagar Station, Surkhet. Department of Hydrology and Meteorology (DHM), Government of Nepal, Kathmandu.

FAO, 2011. Irrigation in Southern and Eastern Asia in figures, AQUASTAT Survey-2011. FAO (Food and Agriculture Organization of the United Nations) water report 37, 33p.

Gurung, A., Adhikari, S., Chauhan, R., Thakuri, S., Nakarmi, S., Ghale, S., Dongol, B. S., and Rijal, D., 2019. Water crises in a water-rich country: case studies from rural watersheds of Nepal's mid-hills. Water Policy, v. 21, pp. 826-847. doi: 10.2166/wp.2019.245

Kansakar, D. R., 2005. Understanding groundwater for proper utilization and management in Nepal. Groundwater Research and Management: Integrating Science into Management Decisions. International Water Management Institute (IWMI), Groundwater Governance in Asia, IWMI-TATA Water Policy Program and National Institute of Hydrology Roorkee, India, $98 \mathrm{p}$.

Kimura, K., 1994. The science reports of the Tohoku university, 7th series (Geography), v. 44(2), pp. 151-181.

Kumar, C., 2012. Climate change and its impact on groundwater resources. International Journal of Engineering Science, v. 1, pp. 43-60.

Mook, W.G., Rozanski, K., and Froelich, K., 2001. Environmental isotopes in the hydrological cycle: Principles and applications. Paris:UNESCO.

Neupane, R., and Shrestha, S.D., 2009. Hydrogeologic assessment and groundwater reserve evaluation in northwestern parts of Dun valley aquifers of Chitwan, inner Terai. Bulletin of the Department of Geology, Tribhuvan University, v. 12, pp. 43-54. doi: https://doi.org/10.3126/bdg.v12i0.2249

Pathak, D., 2016. Water availability and hydrogeological condition in the Siwalik foothill of eastern Nepal. Nepal Journal of Science and Technology, v. 17(1), pp. 31-38. doi: https://doi.org/10.3126/njst.v17i1.25061

Pathak, D., 2017. Delineation of groundwater potential zone in the Indo-Gangetic Plain through GIS analysis. Journal of Institute of Science and Technology, v. 22(1), pp. 104-109. doi: https://doi.org/10.3126/jist.v22i1.17760

Pathak, D., 2018. Status of groundwater exploitation and investigation in Terai and Inner Teri region of Nepal. Bulletin of Nepal Hydrogeological Association. v. 3, pp. 77-83.

Pathak, D., and Shrestha, S.R., 2016. Delineation of groundwater potential zones in rocky aquifers in the mountainous area of Central Nepal. Journal of Nepal Geological Society, v. 50, pp. 161-169. doi: https://doi.org/10.3126/jngs.v50i1.22878 
Pinder, G.F., and Celia, M.A., 2006. Subsurface hydrology. John Wiley and Sons Inc. New Jersey, 468p.

Rao, G. K., R. Shrestha and Y. L. Vaidya. 1996. Hydrogeological conditions in the Terai Plain of Rupandehi district, Lumbini Zone, Nepal with special emphasis on groundwater recharge. In: Proceedings of the international conference on hydrology and water resources, v. 2: Sub Surface Water Hydrology, New Delhi, India, December 1993 (Eds. V. P. Singh and B. Kumar). Springer Science+Business Media Dordrecht. doi: 10.1007/978-94-011-0391-6.

Rao, G.K., and Pathak, D., 1996. Hydrogeological conditions in the Terai plain of Nawalparasi District, Lumbini Zone, Nepal with special reference to groundwater recharges. Journal of Applied Hydrology, v. 9, pp. 69-75.

Rijal, S., Rimal, B., and Sloan, S., 2018. Flood hazard mapping of a rapidly urbanizing city in the Foothills (Birendranagar, Surkhet) of Nepal. Land, v. 7, 60. doi:10.3390/land7020060

Shrestha, S.B., Shrestha, J.N., and Sharma, S.R., 1987. Geological Map of mid-western Nepal (1:250,000). Department of Mines and Geology, Government of Nepal.

Siebert, S., Burke, J., Faures, J.M., Frenken, K., Hoogeveen, J., Döll, P., and Portmann, F.T., 2010. Groundwater use for irrigation - a global inventory. Hydrology and Earth System Sciences., v. 14, pp. 1863-1880. doi:10.5194/hess-14-18632010

Smerdon, B.D., 2017. A synopsis of climate change effects on groundwater recharge. Journal of Hydrology, v. 555, pp. 125 128. doi: 10.1016/j.jhydrol.2017.09.047

Subramanya, K., 2013. Engineering Hydrology (Fourth Ed.). McGraw Hill Education (India) Private Limited, New Delhi, India, ISBN 978-1-25902997-4, 534p.

Todd, D.K., 1980. Groundwater Hydrology (2nd edn). Wiley, New York, ISBN 047108641 X, 552p.

Todd, D.K., and Mays, L.W., 2005. Groundwater Hydrology (3rd edn.), John Wiley and Sons, ISBN: 0-471-05937-4, 656p.

USGS, 2018. Natural processes of ground-water and surfacewater Interaction. https://pubs.usgs.gov/circ/circ1139/htdocs/ natural_processes_of_ground.htm, accessed on June 2018

Villholth, K.G., and Sharma, B.R., 2006. Creating synergy between groundwater research and management in south and south East Asia. In: Groundwater research and management: integrating science into management decisions (Eds. B. S. Sharma and K. G. Villholth).. Proceedings of IWMI-ITPNIH International Workshop on Creating Synergy between Groundwater Research and Management in South and Southeast Asia (Feb. 8-9, 2005) Roorkee, India, pp. 97-98.

Vörösmarty, C.J., Green, P., Salisbury, J., and Lammers, R., 2000. Global Water Resources: Vulnerability from Climate Change and Population Growth. Science, v. 289(5477), pp. 284-288. doi: 10.1126/science.289.5477.284

WWAP. 2009. The United Nations world water development
Report 3: Water in a Changing World, World Water Assessment Programme, Paris, UNESCO Publishing, 349p. 